\title{
CD95 apoptosis resistance in certain cells can be overcome by noncanonical activation of caspase-8
}

\author{
BC Barnhart ${ }^{1}$, EM Pietras ${ }^{1}$, A Algeciras-Schimnich ${ }^{1,4}$, \\ L Salmena ${ }^{2}$, K Sayama ${ }^{3,4}$, R Hakem ${ }^{2}$ and ME Peter ${ }^{\star, 1}$ \\ 1 The Ben May Institute for Cancer Research, University of Chicago, Chicago, \\ IL 60637, USA \\ 2 Department of Medical Biophysics, Advanced Medical Discovery Institute, \\ Ontario Cancer Institute, University of Toronto, Toronto, Ontario, Canada \\ ${ }^{3}$ Shizuoka University, 836 Ohya, Shizuoka-City, Japan \\ ${ }^{4}$ Current address: Abbott Laboratories/Vysis, 3100 Woodcreek Drive, Downers \\ Grove, IL 60515, USA \\ * Corresponding author: ME Peter, Ben May Institute for Cancer Research, \\ University of Chicago, 924 E. 57th Street, Chicago, IL 60637, USA. \\ Tel: + 773 -702 4728; Fax: + $773-702$ 3701; \\ E-mail: MPeter@uchicago.edu
}

Received 07.4.04; revised 28.7.04; accepted 17.8.04; published online 22.10.04 Edited by G Melino

\begin{abstract}
CD95 apoptosis resistance of tumor cells is often acquired through mutations in the death domain (DD) of one of the CD95 alleles. Furthermore, Type I cancer cells are resistant to induction of apoptosis by soluble CD95 ligand (CD95L), which does not induce efficient formation of the death-inducing signaling complex (DISC). Here, we report that tumor cells expressing a CD95 allele that lacks a functional DD, splenocytes from heterozygous $\mathrm{Ipr}^{\mathrm{cg}}$ mice, which express one mutated CD95 allele, and Type I tumor cells stimulated with soluble CD95L can all die through CD95 when protein synthesis or nuclear factor kappa $B$ is inhibited. This noncanonical form of CD95-mediated apoptosis is dependent on the enzymatic activity of procaspase-8 but does not involve fully processed active caspase-8 subunits. Our data suggest that it is possible to overcome the CD95 apoptosis resistance of many tumor cells that do not efficiently form a DISC through noncanonical activation of the caspase-8 proenzyme.

Cell Death and Differentiation (2005) 12, 25-37.

doi:10.1038/sj.cdd.4401509

Published online 22 October 2004
\end{abstract}

Keywords: caspase-8; apoptosis; death domain; tumor cells; CD95; NF-kappaB

Abbreviations: Bio-zVAD, biotinylated zVAD-fmk; CD95L, CD95 ligand; $C H X$, cycloheximide; DD, death domain; $\Delta \Psi_{m}$, change in mitochondrial inner membrane potential; DISC, deathinducing signaling complex; FADD, Fas-associated death domain; FLIP, FLICE-like inhibitory protein; LzCD95L, leucine zipper-tagged CD95L; Ipr, lymphoproliferation; mAb, monoclonal antibody; MAPK, mitogen-activated protein kinase; $\mathrm{NCl}$, National Cancer Institute; NF- $\kappa \mathrm{B}$, nuclear factor kappa B; PARP, poly
(ADP ribose) polymerase; RIP, receptor interacting protein; sCD95L, soluble CD95L; TNF $\alpha$, tumor necrosis factor alpha

\section{Introduction}

CD95 (APO-1/Fas) is a member of the family of death receptors that carry an intracellular death domain (DD) required to initiate the caspase-dependent apoptosis program. The DD of CD95 has been shown to be critical for the recruitment of the adaptor FADD/Mort1, procaspase-8 and -10 and the caspase- $8 / 10$ regulator $c-F L I P_{L}$ and the formation of the DISC. ${ }^{1}$ In Type I cells, active caspase-8 generated at the DISC can directly cleave and activate effector caspase-3, whereas in Type II cells mitochondrial amplification of this signal is required through cleavage of the $\mathrm{BH} 3$ only protein $\mathrm{Bid}$ by a very small amount of caspase- 8 produced at the DISC of Type II cells. ${ }^{2}$

We recently analyzed the 60 tumor cells of the drug screening panel of the National Cancer Institute $(\mathrm{NCl}){ }^{3}$ Among these cells, we identified 22 CD95-sensitive cell lines of which half were classified as Type I and half as Type II. Interestingly, a soluble form of CD95L (sCD95L), S2, was found to selectively induce apoptosis in Type II cells but not in Type I cells despite the fact that Type I cells on average express more CD95 on their cell surface.

Many tumors have been described with mutations in CD95, which presumably arose to avoid destruction via apoptosis. ${ }^{4}$ The vast majority of these mutations are found in the DD, generating a receptor that cannot recruit normal amounts of DD containing proteins, thereby effectively abrogating apoptotic signaling. Interestingly, tumor cells express only one mutant CD95 allele and continue to express one wild-type allele. Nevertheless, such tumor cells are expected to be resistant to CD95-mediated apoptosis due to the dominant negative activity of the mutant allele.,

We now demonstrate that Type I cells can be driven to undergo apoptosis by SCD95L when treated with cycloheximide (CHX) or actinomycin $D(A c t D)$ or inhibitors of nuclear factor kappa B (NF- $k \mathrm{~B})$. Two human tumor cell lines as well as splenocytes from heterozygous $\mathrm{Ipr}^{\mathrm{cg}}$ mice, both of which express a mutant CD95 lacking a functional DD together with a wild-type allele, could also be sensitized to apoptosis by $\mathrm{CHX}$. No evidence for generation of active caspase-8 subunits was found and the caspase-8 selective inhibitor zIETD-fmk was very inefficient in inhibiting this form of apoptosis. However, apoptosis could not be induced in splenocytes from either homozygous $\mathrm{Ipr}^{\mathrm{cg}}$ mice or from T-cell-specific caspase-8-deficient mice. These data suggest that apoptosis can generally be induced in cells that are exposed to $S C D 95 \mathrm{~L}$ or cells that express a mutated CD95 allele breaking the dogma that the activation of caspase-8 at the receptor requires two wild-type CD95 alleles. 


\section{Results}

\section{S2 triggers caspase-dependent apoptosis in Type I cells treated with $\mathrm{CHX}$, ActD or inhibitors of NF- $\kappa \mathrm{B}$}

We have recently shown that $\mathrm{S} 2$, a form of SCD95L, efficiently induces apoptosis in a number of Type II tumor cell lines through a canonical pathway that requires FADD and caspase- $-8{ }^{3}$ In contrast, we demonstrated that Type I cell lines were almost completely resistant to the apoptosisinducing activity of S2 raising the question of whether S2 could be an active apoptosis-inducing ligand for Type I cells as well. We therefore tested whether Type I cells were sensitive to S2 when the apoptosis threshold was lowered by inhibiting protein biosynthesis with $\mathrm{CHX}$. In contrast to apoptosis induction in Type II cells which was not affected by $\mathrm{CHX},{ }^{3}$ both SKW6.4 and H9 cells became highly sensitive to the cytotoxic activity of $\mathrm{S} 2$ when they were coincubated with $\mathrm{CHX}$ (Figure 1a). This effect was not limited to $\mathrm{CHX}$ since it was also observed in cells treated with ActD (Figure 1a). The cytotoxic activity of the S2 preparation was confirmed to be CD95 ligand (CD95L) since both neutralizing anti-CD95 and anti-CD95L antibodies significantly inhibited cell death (as shown for H9 cells, Figure 1a). The observed form of death was apoptosis since zVAD-fmk could block cell death induced by $\mathrm{S} 2$ in $\mathrm{CHX}$ or ActD-sensitized Type I cells and because cells displayed morphological changes typical of cells undergoing apoptosis (data not shown).
To determine whether S2 alone would affect long-term viability of Type I cells, we performed a colony-forming assay (Figure 1b). SKW6.4 cells were plated at different dilutions in 96-well plates (Figure 1b and data not shown). SKW6.4 cells formed an average of one colony per well when plated at 100 cells/well (Figure 1b). To test the effects of S2, CHX and S2/ $\mathrm{CHX}$, we preincubated the cells with the reagents for $8 \mathrm{~h}$ and washed the cells to remove the toxic $\mathrm{CHX}$, added $\mathrm{S} 2$ back where required and plated them in 96-well plates at 100 cells/ well. CHX alone did not affect the ability of SKW6.4 cells to form colonies. S2 alone affected the growth of the colonies as they were smaller (data no shown). However, S2 positively affected the efficiency of these cells to form colonies. In contrast, cells preincubated with $\mathrm{S} 2 / \mathrm{CHX}$ and then cultured with $\mathrm{S} 2$ alone showed a $>95 \%$ reduction in their ability to form colonies (when compared to S2 alone), confirming that S2 can be an effective inducer of apoptosis in Type I cells when protein synthesis is inhibited.

The sensitization of Type I cells to S2-induced apoptosis likely involved the inhibition of $\mathrm{NF}-\kappa \mathrm{B}$ target genes since both the NF- $\kappa$ B inhibitor $\mathrm{CAPE}^{7}$ and Bay 11-7082 (BAY) ${ }^{8}$ could also substantially sensitize cells to apoptosis induction (Figure 1c). Interestingly, SKW6 cells stably expressing Bcl2 could not be sensitized to die by SCD95L, suggesting that the pathway induced in Type I cells by SCD95L when NF- $\kappa$ B is inhibited is dependent on mitochondria and therefore different from the canonical pathway of CD95-induced apoptosis in Type I cells which is independent from mitochondria. ${ }^{9}$
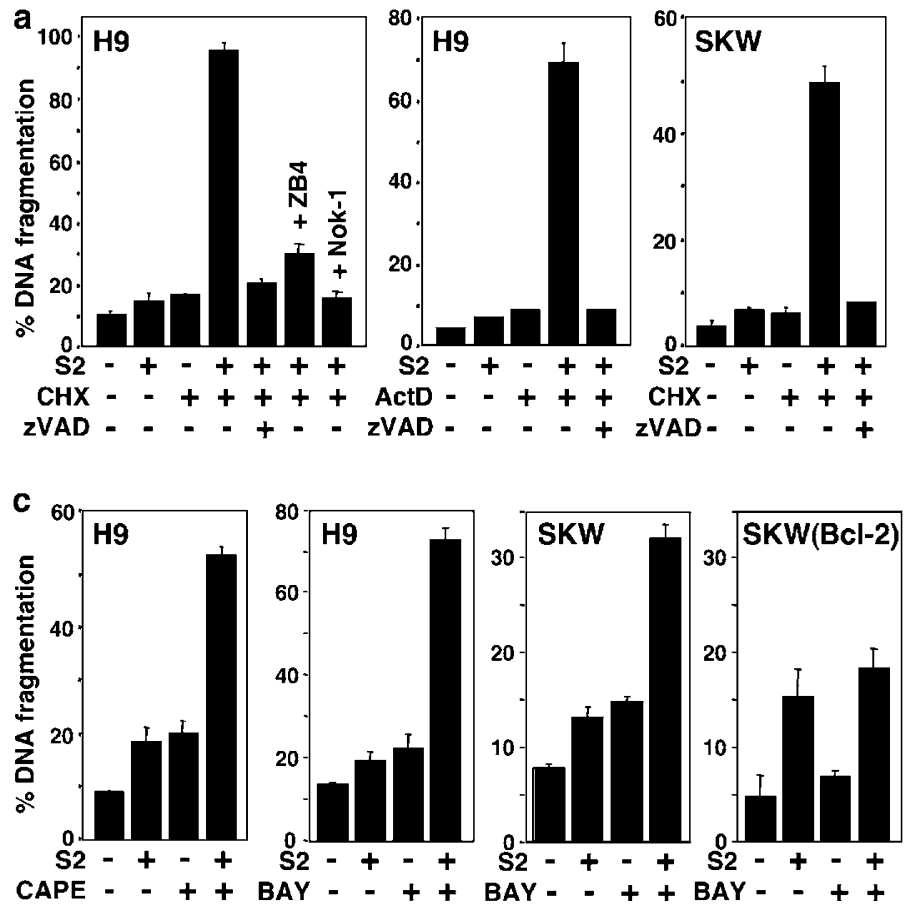

b

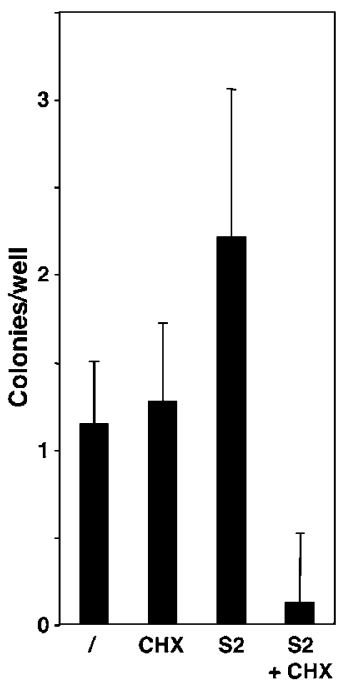

Figure 1 sCD95L induces apoptosis in Type I cells treated with CHX, ActD or inhibitors of NF- $\kappa$ B. (a) H9 cells were pretreated with $2 \mu \mathrm{g} / \mathrm{ml} \mathrm{CHX,100} \mathrm{ng/ml} \mathrm{ActD,} \mathrm{or}$ SKW6. 4 cells were pretreated with $10 \mu \mathrm{g} / \mathrm{ml} \mathrm{CHX.} \mathrm{Cells} \mathrm{were} \mathrm{incubated} \mathrm{with} 1 \mu \mathrm{g} / \mathrm{ml} \mathrm{S2} \mathrm{for} 16 \mathrm{~h}$. Where indicated cells were pretreated 45 min before S2 stimulation with $20 \mu \mathrm{M}$ ZVAD-fmk. S2- and CHX-treated H9 cells were also incubated in the presence of $1 \mu \mathrm{g} / \mathrm{ml}$ ZB4 or Nok-1. (b) SKW6.4 cells were incubated with the indicated reagents for $8 \mathrm{~h}$, washed and plated at 100 cells/well in 96-well plates. 22 was added back where indicated and after 7 days of culture colonies in each well were counted. (c) $\mathrm{H} 9$ cells were treated with $2.5 \mu \mathrm{g} / \mathrm{ml}$ CAPE or $10 \mu \mathrm{M} \mathrm{BAY}$, or SKW6.4 or SKW6(Bcl-2) cells were treated with $5 \mu \mathrm{M}$ BAY and stimulated with $1 \mu \mathrm{g} / \mathrm{ml} \mathrm{S2}$ for $16 \mathrm{~h}$ followed by analysis for DNA fragmentation. All experiments were performed in triplicates. The mean with standard deviation is shown 


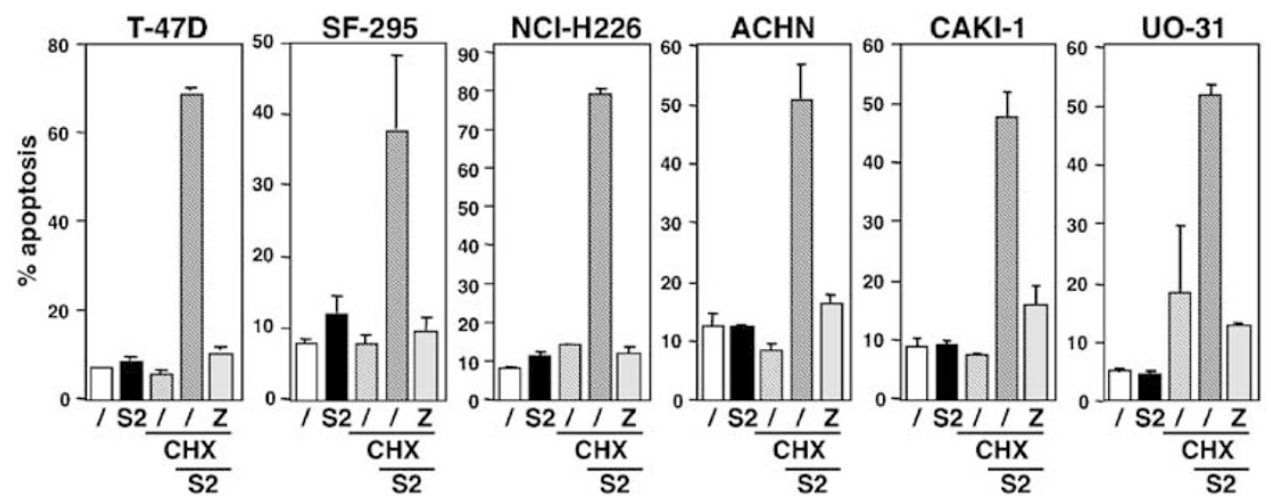

Figure 2 Type I cells are generally sensitive to S2/CHX treatment. A total of six randomly selected Type I cells from the NCl60 tumor cell lines shown to be sensitive to CD95-mediated apoptosis but S2 resistant ${ }^{3}$ were stimulated with $1 \mu \mathrm{g} / \mathrm{ml} \mathrm{S2}$ alone, $1 \mu \mathrm{g} / \mathrm{ml} \mathrm{CHX}$ alone or S2 plus CHX for $16 \mathrm{~h}$ at $37^{\circ} \mathrm{C}$. Where indicated, cells were pretreated 45 min before stimulation with $20 \mu \mathrm{M}$ zVAD-fmk (Z). DNA fragmentation was then quantified. Experiments were performed in triplicates. The mean with standard deviation is shown

We have recently analyzed the 60 tumor cell lines of the drug screen panel of the $\mathrm{NCl}(\mathrm{NCl} 60) .{ }^{3}$ We identified 11 Type I cells among the 22 CD95-sensitive cell lines. None of the Type I cells was sensitive to S2-induced apoptosis and in contrast to Type II cells, all Type I cells could efficiently form a DISC. ${ }^{3}$ We randomly picked six of these cell lines and treated them with $\mathrm{S} 2 / \mathrm{CHX}$. The analysis revealed that all six cell lines underwent apoptosis when incubated with $\mathrm{S} 2$ and $\mathrm{CHX}$ (Figure 2), which was inhibited by zVAD-fmk pretreatment (data not shown). These data confirm that S2 functionally binds to CD95 on the surface of Type I cells and that it can be a cytotoxic ligand for Type I cells albeit with slower kinetics.

\section{S2 does not induce the generation of detectable amounts active caspase- 8 subunits at the DISC in CHX-sensitized Type I cells}

Since S2 alone had no cytotoxic effect on Type I cells, we examined the molecular events that followed ligation of CD95 in these cells. Both anti-APO-1 and a trimerized form of CD95L (leucine zipper-tagged CD95L (LzCD95L)) efficiently induced the recruitment of Fas-associated death domain (FADD) to CD95 in the two Type I but not in the two Type II cells Jurkat and CEM (Figure 3a, lanes 2, 3, 5, 8, 11 and 14). In contrast, S2 stimulation did not result in detectable DISC formation in any of the cells (Figure 3a, lanes 6, 9, 12 and 15). We then tested whether S2/CHX sensitization of Type I cells was a result of more efficient DISC formation. Analysis of the DISC prepared from CHX-treated Type I cells demonstrated that this treatment did not result in an increased recruitment of FADD or caspase-8 (Figure $3 b$ ). Recruitment of FADD and caspase- 8 remained below the detection limit when cells were stimulated for up to $2 \mathrm{~h}$ prior to the analysis of the DISC, suggesting that $\mathrm{S} 2 / \mathrm{CHX}$-induced apoptosis also did not involve a delayed formation of the DISC (Figure $3 b$ ).

We next assayed the activation of caspase-8 and effector caspases $3 / 7$ using a fluorogenic assay and observed that almost undetectable caspase-8 and very little caspase-3-like activity was found in S2-treated SKW6.4 and $\mathrm{H} 9$ cells $2 \mathrm{~h}$ after stimulation (Figure $3 \mathrm{c}$ and $\mathrm{d}$ ). Treatment with $\mathrm{CHX}$ slightly increased caspase-3 activity and very slightly affected activation of caspase-8. To determine the caspase activation profile in S2/CHX-treated cells, we performed a Western blot analysis and examined the processing of various caspases. Even after an extended treatment time of $4 \mathrm{~h}$, a time point at which most cells were dead, no cleavage of caspase- 8 or -10 could be detected, whereas processing of caspases 3, 7 and to a lesser extent 6 and 9 was observed (Figure $3 e$ ). Interestingly, Bid was partially degraded in S2/CHX-treated cells suggesting that caspase- 8 activity was present.

\section{Mitochondrial activation in S2/CHX-treated cells is mediated by a caspase which is poorly inhibited by the selective caspase-8 inhibitor zIETD-fmk}

Since Type I cells treated with S2/CHX did not generate detectable amounts of caspase- 8 activity, we tested the sensitivity of this form of apoptosis to the caspase- 8 selective inhibitor zIETD-fmk. $\mathrm{H} 9$ cells stimulated with either S2/CHX or LzCD95L were incubated with increasing concentrations of zVAD-fmk, zIETD-fmk or the caspase-10 selective inhibitor zAEVD-fmk (Figure 4a). In cells treated with LzCD95L, all three inhibitors were equally effective at inhibiting CD95mediated apoptosis, due to the dependence of the canonical pathway on the initiator caspases. In contrast, whereas zVADfmk was as efficient at inhibiting S2/CHX-mediated apoptosis as LzCD95L-mediated apoptosis, both zIETD-fmk and zAEVD-fmk were much less efficient. Taken together our data suggest the involvement of a caspase activity distinct from the classical caspase- 8 heterotetramer in an unusual form of CD95-mediated apoptosis. This form of cell death does not represent necrosis since we observed both rapid DNA fragmentation and breakdown of mitochondrial membrane potential $\left(\Delta \Psi_{\mathrm{m}}\right)$ in these cells (see below).

To determine where in the apoptotic pathway Type I cells are sensitized to S2-induced apoptosis by $\mathrm{CHX}$, we treated cells with S2 and determined the $\Delta \Psi_{\mathrm{m}}$ (Figure $4 \mathrm{~b}$ ). We did not detect a change in the $\Delta \Psi_{\mathrm{m}}$ in SKW6.4 cells treated with $\mathrm{S} 2$ alone (Figure 4b). However, CHX-sensitized cells showed a marked decrease in $\Delta \Psi_{\mathrm{m}}$. Consistent with our inhibitor 
a

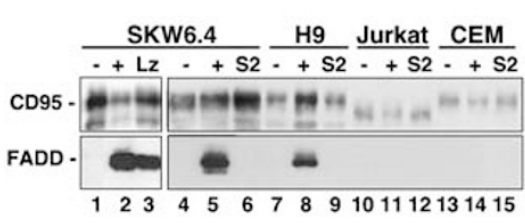

C

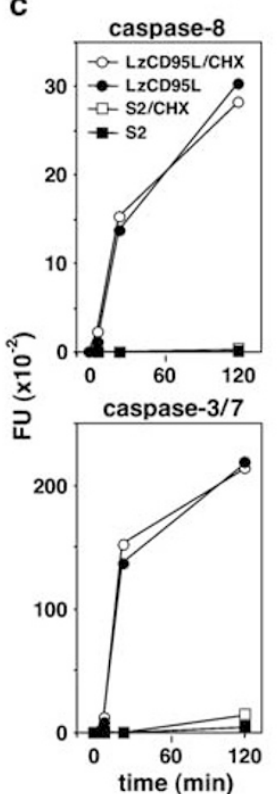

d

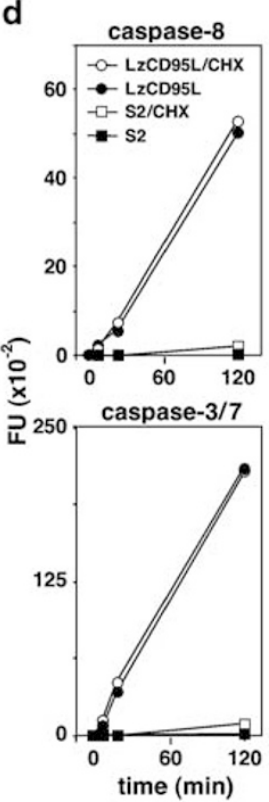

SKW6.4

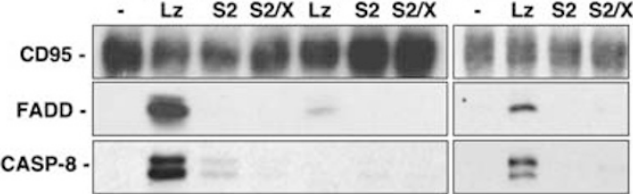

e

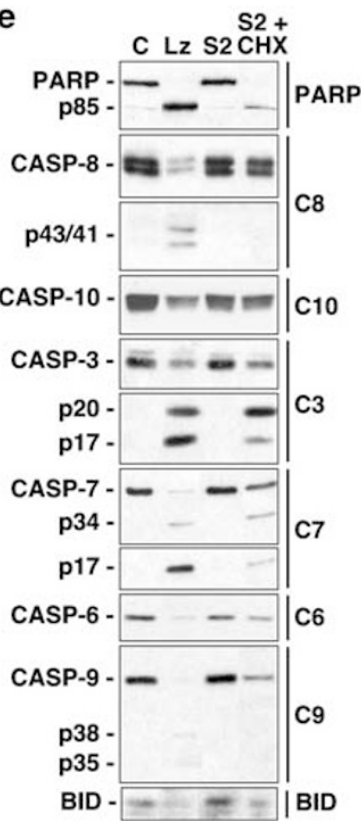

Figure $3 \mathrm{sCD} 95 \mathrm{~L} / \mathrm{CHX}$ treatment of Type I cells does not induce measurable DISC formation or significant caspase-8 activation. (a) CD95 was immunoprecipitated from unstimulated (-) or anti-APO-1 ( +), LzCD95L (Lz) or S2-treated cells. Immunoprecipitates were subjected to 12\% SDS-PAGE and immunoblotted with anti-FADD and anti-CD95 (C20) antibodies. (b) CD95 was immunoprecipitated from unstimulated (-), LzCD95L (Lz), S2, or S2 plus CHX (10 $\mu$ g/ml) (S2/X)-treated SKW6.4 (for the indicated times) and $\mathrm{H} 9$ (stimulated for $10 \mathrm{~min}$ ) cells. Immunoprecipitates were subjected to $12 \%$ SDS-PAGE and immunoblotted with anti-FADD, anti-caspase-8 and anti-CD95 (C20) antibodies. (c) SKW6.4 and (d) H9 cells were pretreated with $\mathrm{CHX}$ for $1 \mathrm{~h}$ at $37^{\circ} \mathrm{C}$ and then stimulated with $1 \mu \mathrm{g} / \mathrm{ml}$ of S2 or LzCD95L for the indicated times. After stimulation, cells were lysed and caspase-8 and -3 enzymatic activity was analyzed by cleavage of the fluorogenic substrates IETD-AFC and DEVD-AFC, respectively. The experiments in (c) and (d) are representative of three independent experiments. (e) SKW6.4 cells were left untreated (C) or were stimulated with LzCD95L (Lz), S2 or S2 plus $10 \mu \mathrm{g} / \mathrm{ml} \mathrm{CHX} \mathrm{for} 4 \mathrm{~h}$. Cell lysates equivalent to $50 \mu \mathrm{g}$ of protein were subjected to $12 \%$ SDS-PAGE and immunoblotted with the indicated antibodies. The migration positions of each protein are shown. C, caspase

studies, treatment with zIETD-fmk did not significantly reduce the S2-induced drop in $\Delta \Psi_{\mathrm{m}}$ in CHX-treated SKW6.4 cells whereas ZVAD-fmk significantly prevented it (Figure 4c), suggesting that a caspase other than the classical active caspase-8 connects the S2-triggered CD95 receptor to the mitochondria. Similar results were obtained when H9 cells were tested (Figure 4c). Inhibitors selective for caspases 1/4/ 5, 2, 3/7, 6, 9 and 10 also did not inhibit the drop in $\Delta \Psi_{\mathrm{m}}$ (Figure 4d and data not shown). Our data therefore argued against the involvement of the canonical active caspase- 8 in this pathway. A number of other proteases have been linked to death receptor signaling although they have never directly been shown to be involved in CD95 signaling: cathepsin $\mathrm{B},{ }^{10}$ calpain ${ }^{11}$ and serine proteases. ${ }^{12}$ To test the involvement of any of these three classes of proteases in this nonclassical pathway, we titered the cathepsin B/K inhibitor zFA-fmk, the calpain inhibitor $z L L Y$-fmk and the general serine protease inhibitor AEBSF onto $\mathrm{H} 9$ cells and then treated them with $\mathrm{S} 2 /$ $\mathrm{CHX}$ (Figure $4 \mathrm{e}$ ). None of these inhibitors significantly inhibited S2/CHX-mediated apoptosis at concentrations up to $50 \mu \mathrm{M}$ (500 $\mu \mathrm{M}$ for AEBSF). In contrast, zVAD-fmk was very effective at inhibiting apoptosis at concentrations as low as $5 \mu \mathrm{M}$ in this experiment. Our data suggest that a caspase that is inefficiently inhibited by zIETD-fmk but very efficiently inhibited by zVAD-fmk mediates CD95-induced apoptosis by the sCD95L S2 in Type I cells when protein synthesis is inhibited.

\section{Induction of apoptosis in tumor cells through CD95 expressing a CD95 mutant allele that lacks a functional DD}

Our data so far suggested that under certain circumstances CD95 can induce apoptosis without the need to process and release large amounts of active caspase-8 at the DISC, raising the question of whether a functional DD in CD95, a prerequisite for DISC formation, was required for this form of CD95-induced apoptosis. 


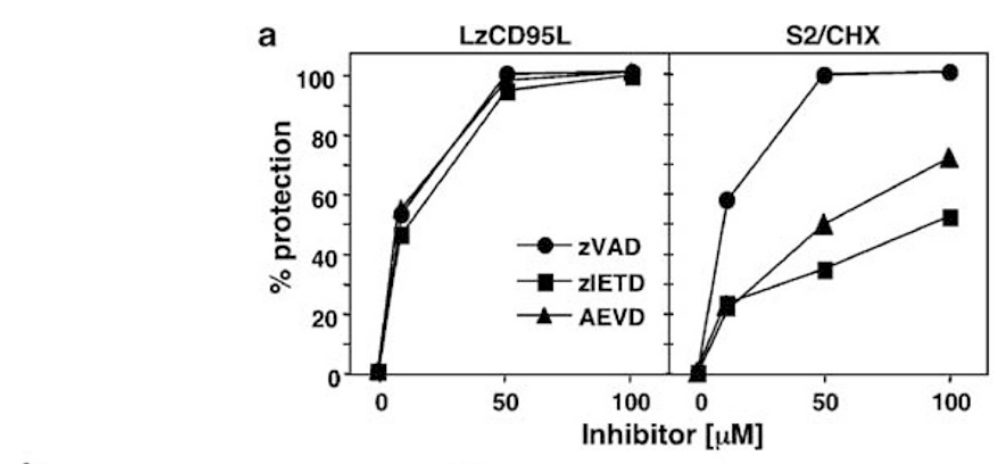

b

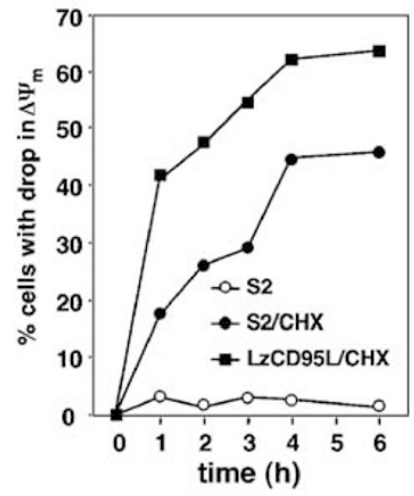

C



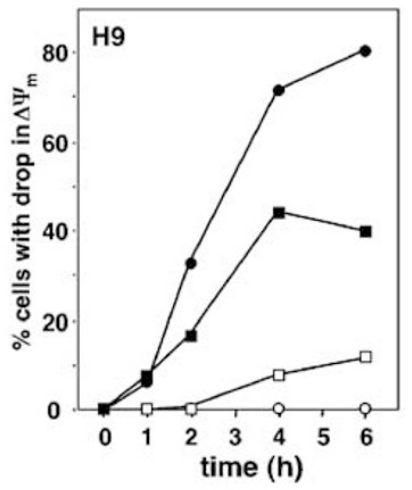

d

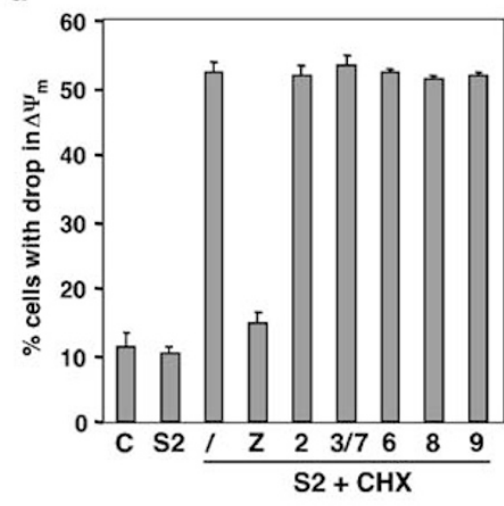

e



Figure 4 Apoptosis mediated through $\mathrm{S} 2 / \mathrm{CHX}$ is caspase dependent but occurs independently of canonical initiator caspases activity. (a) $\mathrm{H} 9$ cells were pretreated with

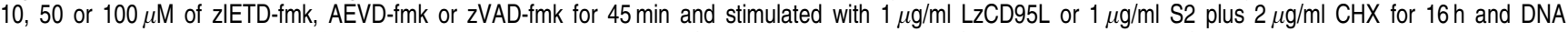
fragmentation was quantified. (b) SKW6.4 cells were stimulated with $1 \mu \mathrm{g} / \mathrm{ml} \mathrm{S} 2$ alone and S2 or $1 \mu \mathrm{g} / \mathrm{ml} \mathrm{LzCD95L} \mathrm{plus} 10 \mu \mathrm{g} / \mathrm{ml} \mathrm{CHX}$ at $37^{\circ} \mathrm{C}$ for the indicated times. Drop in $\Delta \Psi_{\mathrm{m}}$ was determined by staining with MitoShift as described in Materials and Methods. (c) SKW6.4 or H9 cells were treated with $1 \mu \mathrm{g} / \mathrm{ml}$ S2 alone or S2 plus 10 or $2 \mu \mathrm{g} / \mathrm{ml} \mathrm{CHX}$, respectively, for the times indicated. Cells pretreated for 45 min were shown with $50 \mu \mathrm{M}$ zVAD-fmk or zIETD-fmk. Drop in $\Delta \Psi_{\mathrm{m}}$ was determined by staining with MitoShift. (d) SKW6.4 cells were stimulated for $4 \mathrm{~h}$ as indicated and analyzed as in (c) but pretreated with caspase inhibitors selective for the denoted caspases. The experiment was performed in triplicates. The mean with standard deviation is shown. (e) H9 cells were pretreated with different inhibitors for 45 min and stimulated with $1 \mu \mathrm{g} / \mathrm{ml} \mathrm{S2}$ plus $2 \mu \mathrm{g} / \mathrm{ml} \mathrm{CHX}$ for $16 \mathrm{~h}$ and DNA fragmentation was quantified. The experiments in (a), (b), (c) and (e) are representative of three independent experiments

It is well established that tumor cells can acquire mutations in CD95 that disable its apoptotic signaling. Therefore, CD95 has been considered a tumor suppressor gene. ${ }^{13}$ Interestingly, an analysis of 17 publications reporting mutations in CD95 (a total of 95 mutations) in tumor cells revealed that most of the mutations occur in exon 9, the exon coding for the DD (Figure 5a). The mutational frequency in exon 9 is about eight times higher when compared to the mutational frequency in the juxtamembrane domain (exon 7) (unpub- lished results). This observation is consistent with the concept that tumors gain a growth/survival advantage when the canonical apoptosis-inducing pathway of CD95 is disabled. ${ }^{14}$ The current dogma of CD95 signaling dictates that caspase-8 must be activated at the DISC through induced proximity and that this is dependent on at least three functional DDs that must be present in a trimerizing or oligomerized CD95 receptor. Overexpression of a CD95 receptor that carries a nonfunctional DD has been shown to dominant negatively 


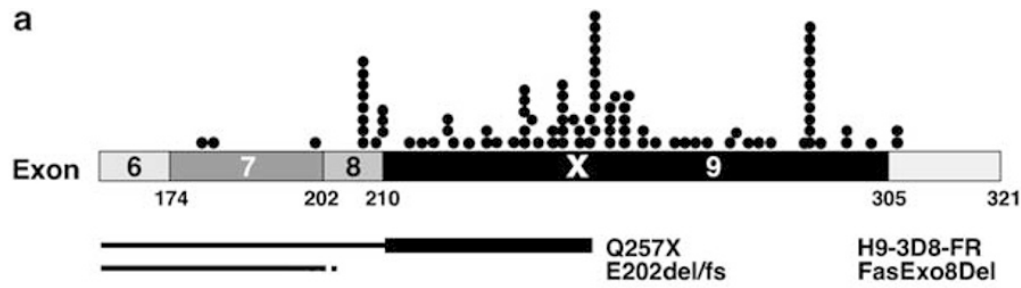

b


Figure 5 Apoptosis mediated through SCD95L and CHX occurs in tumor cells expressing a DD-deficient CD95 mutant allele. (a) Locations of mutations in CD95 reported for various different tumor types derived from a recent analysis of 17 publications describing 95 mutations in the cytoplasmic tail of CD95 in human tumors. ${ }^{39}$ Each dot represents the position of a reported nonsense, missense and frameshift mutation or mutations in introns that prevent proper splicing, resulting in truncated receptors lacking exon 8. The position of the $\mathrm{lpr}{ }^{\mathrm{cg}}$ mutation found in mouse CD95 is labeled by a white $\times$ in the DD (black box). The mutated CD95 receptors expressed in two recently described mutant T-cell lines are shown schematically. H9-3D8-FR mutant cells express a CD95 receptor in which glutamine 257 is replaced by a stop codon, the FasEx08Del H9 mutant cell line expresses CD95 with a deletion/frameshift mutation at glutamic acid 202. (b) H9 mutant cell line H9-3D8-FR and Hut78 mutant cell line FasExo8Del both expressing CD95 lacking a functional DD (see a) were stimulated at $37^{\circ} \mathrm{C}$ with $1 \mu \mathrm{g} / \mathrm{ml}$ anti-APO-1 or S2 alone, $1 \mu \mathrm{g} / \mathrm{ml} \mathrm{CHX}$ alone $(2 \mu \mathrm{g} / \mathrm{ml}$ for the $\mathrm{H} 9$ mutant cell) or anti-APO-1/S2 plus $\mathrm{CHX}$ for $16 \mathrm{~h}$ and DNA fragmentation was quantified. Cells were pretreated 45 min before stimulation as indicated with $20 \mu \mathrm{M}$ of the caspase inhibitors zVAD-fmk (Z) or zIETD-fmk (I). (c) Mutant cell lines and their respective parental cells H9 and HUT78, respectively, were treated with anti-APO-1 or S2 for $2 \mathrm{~h}$ either untreated $(-)$ or pretreated $(+)$ with $\mathrm{CHX}(1 \mu \mathrm{g} / \mathrm{ml})$. IETDase (CASP-8) and DEVDase (CASP-3/7) activity of cell extracts was determined as described in Figure 3c. The analysis is representative of three independent experiments. Background values were subtracted. (d) CD95 was immunoprecipitated from unstimulated (C), anti-APO-1 (A), S2, or S2 plus CHX $(1 \mu \mathrm{g} / \mathrm{ml})$ (S2/X)-treated H9-3D8-FR and FasEx08Del cells for 10 min. Immunoprecipitates were subjected to $12 \%$ SDS-PAGE and immunoblotted with anti-FADD and anti-caspase-8. Experiments in (b) and (c) were performed in triplicates. The mean with standard deviation is shown

interfere with apoptotic CD95 signaling. ${ }^{5,6}$ Interestingly, many reported tumors expressing mutated CD95 only carry one mutated CD95 allele which should completely prevent formation of the DISC and render these tumor cells resistant to CD95-mediated apoptosis.

A few human tumor cell lines have been reported that express one mutated and one wild-type CD95 allele, mimicking the expression profile of similar tumors. ${ }^{15,16}$ These cell lines, which were selected by extended culture in the presence of agonistic anti-CD95 antibodies, are derivatives of highly CD95 apoptosis-sensitive Type I cell lines, and have been shown to be completely resistant to treatment with antiCD95 antibodies. We tested two such cell lines, the H9 variant H9-3D8-FR ${ }^{15}$ and the Hut78 variant FasExo8Del ${ }^{16}$ for sensitivity to apoptosis in the presence of $\mathrm{CHX}$ (Figure 5). H9-3D8-FR cells express a CD95 receptor that carries a stop codon at amino-acid position 257 in the middle of the DD and FasExo8Del cells express a truncated CD95 receptor that lacks exons 8 and 9 (Figure 5a). Our analysis confirmed that both cell lines were highly resistant to the effects of anti-CD95 
mAb (Figure 5b). Interestingly, it was previously shown that H9-3D8-FR cells become sensitive to CD95-induced apoptosis when treated with $\mathrm{CHX}$ and this sensitivity was inhibited by zVAD-fmk, ${ }^{15}$ mirroring our results with wild-type H9 cells treated with $\mathrm{S} 2 / \mathrm{CHX}$. Additionally, this observation suggests that the nature and level of caspases activated in S2/CHXtreated Type I cells may be similar to that found in tumor cells expressing mutated CD95 treated with anti-CD95/CHX. To test this hypothesis, we compared apoptosis in H9-3D8-FR and FasExo8Del cells induced by $\mathrm{S} 2$ or anti-APO-1 (Figure 5b). Both stimuli caused apoptosis only in $\mathrm{CHX}$ treated mutant cells and in both cases zVAD-fmk but not zIETD-fmk efficiently blocked apoptosis induction. Similar to S2/CHX-treated Type I cells, virtually no caspase-8 and little caspase-3 activity was detected in the two mutant cells treated with either S2 or anti-APO-1 regardless of whether the cells were pretreated with $\mathrm{CHX}$ (Figure $5 \mathrm{c}$ ). In contrast, antiAPO-1 stimulation of the parental cell lines expressing two CD95 wild-type alleles resulted in robust activation of both initiator and effector caspases consistent with the results in Figure $3 c$ and $d$. These data suggest that even tumor cells expressing a CD95 mutant allele can be forced to undergo apoptosis induced through CD95. A DISC analysis of the mutant cells and their parental cells showed that when stimulated with anti-APO-1, the cells expressing the mutant CD95 allele did recruit small amounts of both FADD and caspase-8 to the DISC without signs of caspase-8 activation (Figure 5d). However, no recruitment was detected in either wild-type or S2/CHX-treated mutant cells. Since both mutant cell lines were equally resistant to anti-APO-1 or S2, this raised the question of whether the canonical DISC and caspase- 8 were required for the apoptosis observed in these cells.

\section{CD95-mediated apoptosis in CHX-treated cells critically depends on caspase-8 and at least one wild-type CD95 allele}

There are no human cells known that express two alleles of mutant CD95. Therefore, to determine whether cells expressing two mutant alleles of CD95 are fully resistant to CD95mediated apoptosis even in the presence of $\mathrm{CHX}$, we used $\mathrm{Ipr}^{\mathrm{cg}}$ mice that express a CD95 receptor with a point mutation in the $D D^{17}$ (see Figure 5a).

We first tested the sensitivity of splenocytes from wild-type mice that had been activated for 4 days with anti-CD3 and IL-2 to LzCD95L, S2 or the anti-mouse CD95-specific agonistic antibody Jo2 in the absence and presence of $\mathrm{CHX}$ (Figure 6a, left panel). LzCD95L was very effective in killing these cells with little augmentation in the presence of $\mathrm{CHX}$. In contrast, apoptosis of splenocytes induced by the agonistic monoclonal antibody (mAb) Jo2 (which is a much weaker stimulus) was greatly enhanced by treatment with $\mathrm{CHX}$. S2 also efficiently induced apoptosis in these cells, which was enhanced by $\mathrm{CHX}$. In splenocytes from homozygous $\mathrm{C} 3 \mathrm{H}^{\mathrm{lpr}(\mathrm{cg}) / \mathrm{lpr}(\mathrm{cg})}$ mice, none of the CD95 stimuli efficiently induced apoptosis regardless of whether $\mathrm{CHX}$ was added (Figure 6a, right panel). To mimic the situation found in human tumors that express a mutated CD95 allele, we generated heterozygous
$\mathrm{C} 3 \mathrm{H}^{\mathrm{wt} / \mathrm{lpr}(\mathrm{cg})}$ mice. In activated splenocytes from these mice, which express only one mutant CD95 allele, stimulation with LzCD95L weakly induced apoptosis which was substantially enhanced with $\mathrm{CHX}$ treatment (Figure 6a, center panel). S2 was not very effective in inducing apoptosis even at the highest concentration of $10 \mu \mathrm{g} / \mathrm{ml}$. However, at any concentration of S2, CHX treatment significantly enhanced S2induced apoptosis. These results indicate that induction of apoptosis through CD95 requires the presence of at least one functional DD and complete blockage of CD95-mediated apoptosis occurs only when both alleles of CD95 are mutated. To test whether apoptosis induced by $\mathrm{S} 2 / \mathrm{CHX}$ in primary mouse cells involved processing of caspase-8, we performed a Western blot analysis of caspase-8 in splenocyte extracts from the three mice strains (Figure 6b). Consistent with the data on apoptosis sensitivity LzCD95L induced massive processing of caspase- 8 in wild-type cells and very little processing of caspase- 8 in heterozygous cells. In contrast, $\mathrm{S} 2 / \mathrm{CHX}$ induced little caspase-8 processing in wild-type cells and no detectable processing in heterozygous cells. No caspase processing was detectable by any stimulus in $\mathrm{Ipr}^{\mathrm{cg} /}$ $\mathrm{Ipr}^{\mathrm{cg}}$ mice. These data suggest that $\mathrm{S} 2 / \mathrm{CHX}$ in mouse cells also triggers apoptosis without any measurable processing of procaspase-8. To test whether caspase-8 was still required for this form of apoptosis, we analyzed splenocytes from $\mathrm{T}$ cell-specific caspase-8 knockout mice ${ }^{18}$ (Figure 6c). Even with the strongest stimulus used in our study (LzCD95L) and the presence of $\mathrm{CHX}$, apoptosis was not induced in these cells. These cells were also completely refractory to CD95induced apoptosis when treated with either S2/CHX or the agonistic anti-CD95 mAb Jo2 and CHX (data not shown). Similar data were obtained by testing thymocytes from these mice (data not shown).

\section{sCD95L/CHX induces apoptosis which depends on the proteolytic activity of the caspase-8 proenzyme}

Our experiments strongly suggest that CD95-mediated apoptosis critically depends on the presence of procaspase8 even in the presence of $\mathrm{CHX}$. We have recently shown that the first caspase-8 activity that can be detected upon engagement of CD95 is by the proform of caspase-8. ${ }^{19}$ Furthermore, we determined that procaspase- 8 and active caspase-8 subunits released from the DISC have different substrate specificities, ${ }^{19}$ providing an explanation for the different sensitivities of the two forms of CD95-mediated apoptosis described in this report to different caspase inhibitors. We therefore postulated that low concentrations of zVAD-fmk would inhibit both active procaspase-8 as well as DISC released active caspase-8, whereas zIETD-fmk would only inactivate the mature fully processed enzyme in the cytosol. To test whether different steps of caspase-8 activation respond differently to the two peptide inhibitors, we tested MCF7-Fas-Bcl- $x_{\mathrm{L}}$ cells. The stable expression of $\mathrm{Bcl}-\mathrm{x}_{\mathrm{L}}$ in this unique cellular model allowed us to test the effects of the two inhibitors on caspase- 8 processing in cells that do not undergo apoptosis yet efficiently process procaspase-8 following triggering of CD95. ${ }^{20}$ Both inhibitors efficiently 
a



b

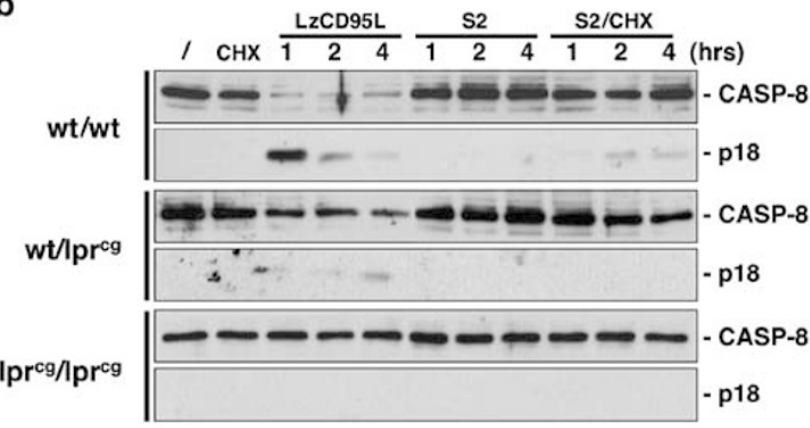

c



Figure 6 Apoptosis induced by CD95L requires expression of at least one wild-type CD95 allele and expression of procaspase-8. (a) Activated splenocytes from the indicated mouse strains were treated for $22 \mathrm{~h}$ with $1 \mu \mathrm{g} / \mathrm{ml} \mathrm{LzCD95L} \mathrm{(Lz),} 1 \mu \mathrm{g} / \mathrm{ml} \mathrm{S2}$ or $10 \mu \mathrm{g} / \mathrm{ml}$ agonistic mouse anti-CD95 antibody Jo2 (with $10 \mathrm{ng} / \mathrm{ml}$ protein A to achieve crosslinking), in the presence or absence of $\mathrm{CHX}(0.1 \mu \mathrm{g} / \mathrm{ml})$. Cells were harvested and DNA fragmentation was determined. (b) Cell lysates $(20 \mu \mathrm{g})$ from activated splenocytes stimulated as labeled of indicated mouse strains were subjected to immunoblot analysis using an anti-mouse caspase-8 antibody. Migration positions of the proform as well as the active p18 subunit are indicated. (c) Activated splenocytes from the indicated mouse strain were treated with LzCD95L in the presence or absence of $(10 \mu \mathrm{g} / \mathrm{ml}) \mathrm{CHX}$. DNA fragmentation was then determined. Experiments in (a) and (c) were performed in triplicates. The mean with standard deviation is shown

blocked CD95-mediated apoptosis in the apoptosis-sensitive vector-transfected MCF7-Fas cells (data not shown). However, they had very different efficiencies in blocking the processing of caspase-8 (Figure 7a). Whereas ZVAD-fmk completely prevented appearance of any caspase-8 cleavage fragments, zIETD-fmk had virtually no effect on the appearance of the cleavage intermediates p43/p41 which are generated in the DISC. ${ }^{21}$ Two smaller processed caspase-8 subunits appeared but had different molecular weights when compared to the active p18 subunits generated in cells that were not treated with inhibitors. Caspase- 8 is efficiently inhibited by the cow pox virus serpin crmA. ${ }^{22}$ While it was shown that crmA inhibits active caspase- $8^{22}$ we previously reported that $\mathrm{crmA}$ does not affect the processing of procaspase- 8 in the DISC, ${ }^{21}$ indicating that crmA only binds to the mature fully processed caspase- 8 released from the DISC. We therefore tested BJAB cells stably expressing similar amounts of either an inactive crmA mutant ( $\left.\mathrm{crmA}^{\mathrm{mut}}\right)$ or wild-type $\mathrm{crmA}\left(\mathrm{crmA}^{\mathrm{wt}}\right) .^{21} \mathrm{crmA}^{\text {mut }}$ did not interfere with either LzCD95L or S2/BAY-induced apoptosis (Figure 7b). In contrast, crmA ${ }^{\text {wt }}$ efficiently blocked LZCD95L-induced apoptosis but very marginally inhibited S2/BAY-induced apoptosis. In contrast, a dominant negative form of FADD (FADD-DN) efficiently blocked any form of CD95-induced apoptosis (Figure 7b). Our data therefore suggested that both FADD and caspase- 8 are required for the novel form of CD95mediated apoptosis induced by $\mathrm{S} 2 / \mathrm{CHX}$; thus, it is not the active form of caspase- 8 but procaspase- 8 that is activated. To directly identify the form of caspase-8 that is activated in S2/CHX-treated cells, we incubated CD95L-treated SKW6.4 cells with biotinylated zVAD-fmk (bio-zVAD) which covalently labels enzymatically active caspases, and after lysis pulled down biotinylated proteins with streptavidin agarose beads, followed by detection of labeled caspases with the appropriate antibodies (Figure 7c). Interestingly in resting cells, bio-zVAD labeled procaspase-8 (Figure 7c, lane 1 and 2). After 


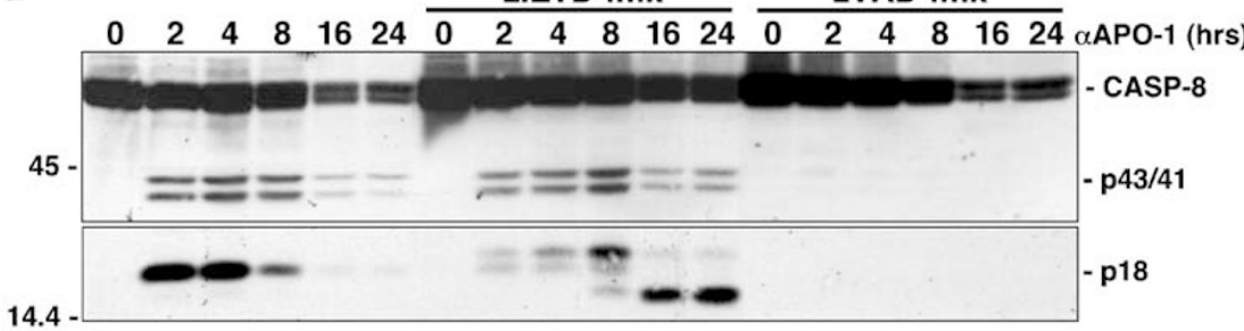

b



C



Figure 7 Apoptosis induced by S2/CHX involves active procaspase-8 but not caspase-8 active subunits. (a) MCF7-Fas-Bcl-X cells were preincubated with $40 \mu \mathrm{M}$ of the indicated caspase inhibitor and stimulated with $1 \mu \mathrm{g} / \mathrm{ml}$ anti-APO-1 and $1 \mathrm{ng} / \mathrm{ml}$ protein A for the indicated times. Cell lysates were subjected to $12 \%$ SDS-PAGE and immunoblotted with a antibody to caspase-8. (b) BJAB cells expressing either mutant crmA or wild-type crmA or FADD-DN were stimulated with $1 \mu \mathrm{g} / \mathrm{ml}$ S2 in the

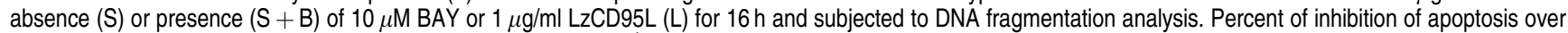
control cells (vector transfectants in case of FADD-DN and crmA ${ }^{\text {mut }}$-expressing cells in case of crmA transfectants) was determined. The experiment was performed in triplicates and the mean values and standard deviation are shown. (c) SKW6.4 cells were stimulated as indicated and incubated with bio-zVAD, lysed and incubated with streptavidin-agarose beads, followed by immunoblot analysis using caspase-8 or caspase-3 specific antibodies

treatment with LzCD95L, procaspase-8 was completely converted to active caspase-8 with the p18 subunit efficiently labeled by bio-zVAD (Figure 7c, lanes 3-5). S2 alone which did not induce apoptosis did not cause a change in labeled caspase-8 (Figure 7c, lanes 6-8). In contrast, in cells treated with $\mathrm{S} 2 / \mathrm{CHX}$, which died very effectively, labeled full-length caspase-8 declined without significant formation of the $\mathrm{p} 18$ subunit (Figure 7c, lanes 10 and 11). In contrast, procaspase-3 could not be detected in a bio-zVAD-labeled form but active caspase-3 subunits were efficiently labeled by bio-zVAD in both cells treated with LzCD95L and somewhat less efficiently in cells treated with $\mathrm{S} 2 / \mathrm{CHX}$. In summary, our results suggest that in the noncanonical pathway detected in Type I cells stimulated with $\mathrm{S} 2 / \mathrm{CHX}$ or in cells expressing one mutant CD95 allele, procaspase-8 is activated at the CD95 receptor without the requirement for classical DISC formation or the requirement for fully mature caspase-8 heterotetramers.

\section{Discussion}

It has been shown that SCD95L is significantly less active than membrane bound CD95L in inducing apoptosis. ${ }^{23,24} \mathrm{We}$ recently found that $S C D 95 \mathrm{~L}$ can induce apoptosis in Type II cells but that it is not toxic to Type I cells. ${ }^{3}$ We now present evidence that SCD95L activates apoptosis in Type I cells as well when protein biosynthesis (or RNA synthesis) is blocked by treatment with either $\mathrm{CHX}$ or ActD. This situation is similar to induction of apoptosis by soluble TNF $\alpha$ that only induces apoptosis in most normal cells and tumor cell lines when protein biosynthesis is inhibited. ${ }^{25}$ It is believed that TNF $\alpha$ induces activation of antiapoptotic genes largely through transcriptional activation involving activation of $\mathrm{NF}-\kappa \mathrm{B}$. A reduction in NF- $\kappa \mathrm{B}$ activity could also be involved in the sensitization of cells to SCD95L since both selective NF- $\kappa$ B inhibitors CAPE and BAY also effectively sensitized these cells. This would be consistent with our recent finding that NF$\kappa \mathrm{B}$ is activated through CD95 in the majority of CD95 apoptosis-resistant tumor cells including Type I cells stimulated with SCD95L. ${ }^{14} \mathrm{CHX}$ and ActD are used to sensitize drug-resistant tumor cells to death receptor-mediated apoptosis. It is generally believed that this treatment results in downregulation of short-lived antiapoptotic proteins such as the NF- $\kappa$ B-regulated c-FLIP ${ }^{26}$ and that once such a 'brake' has been removed cells die through the canonical pathway. Future studies will have to determine which NF- $\kappa$ B-regulated genes are involved in the resistance of Type I cells to SCD95Linduced apoptosis. 
Studies on CD95 signaling have focused almost exclusively on the DD and the subsequent formation and activation of the DISC. CD95-mediated apoptosis is believed to be strictly caspase-8 dependent and signaling pathways emanating from CD95 require the CD95 DD. According to this dogma, only one mutated receptor in a receptor trimer would be sufficient to dominant negatively inhibit apoptotic CD95 signaling. The DISC would therefore not form in these cells and they would be rendered resistant to CD95-mediated apoptosis. ${ }^{6}$ Our work now demonstrates that apoptosis can be induced in cells expressing mutant and wild-type CD95 receptors at a ratio of $1: 1$ when the apoptosis threshold is lowered, for example, by treatment with $\mathrm{CHX}$.

It has been shown that CD95 can also induce necrosis in certain cells. ${ }^{27}$ In these cases, inhibition of caspases by zVAD-fmk can redirect cell death towards necrosis. In fact, treatment of CD95-stimulated L929 cells with zVAD-fmk results in an acceleration of cell death rather than its inhibition. ${ }^{28}$ In contrast, the cell death detected in our work is apoptosis in all cases since it was efficiently blocked by low concentrations of zVAD-fmk, the caspase substrate PARP was cleaved, cells showed morphological features typical for apoptosis, and fragmented DNA in a fashion that was only seen in apoptosing cells.

It was recently demonstrated that the first caspase-8 activity detected in CD95-stimulated cells is the activity of DISCassociated procaspase-8. ${ }^{19}$ To identify the caspase activity that is executing apoptosis in S2/CHX-treated cells, we covalently labeled active caspases with bio-zVAD. Interestingly in cells dying through the canonical pathway induced by LzCD95L, only active caspase-8 subunits were labeled. In contrast, in cells treated with $\mathrm{S} 2 / \mathrm{CHX}$, active caspase-8 was virtually undetectable and only full-length caspase-8 was labeled by bio-zVAD. Over time, the amount of procaspase-8 declined suggesting that procaspase-8 was active and underwent degradation. At the same time, labeled active caspase- 3 subunits formed.

CD95-mediated apoptosis described in our study was different from the canonical CD95 pathway usually found in Type I cells in the following ways: (1) no DISC was detectable, (2) we could not detect caspase-8 processing by Western blotting, (3) only full-length caspase-8 was found to be labeled in bio-zVAD-treated cells, (4) no enzymatic caspase-8 activity was detected, (5) this form of apoptosis could not be efficiently inhibited by the caspase- 8 inhibitor zIETD-fmk, (6) crmA did not block this form of apoptosis, (7) the drop of $\Delta \Psi_{m}$ caused by S2 in $\mathrm{CHX}$-sensitized cells could not be prevented by pretreating cells with zIETD-fmk and (8) this apoptosis pathway could be induced in cells expressing a mutated CD95 receptor lacking a functional DD.

Regardless of the differences between this pathway and the classical CD95-mediated form of apoptosis, the CD95 DD, FADD and caspase- 8 are still required in the noncanonical pathway since cells from mice expressing two mutant CD95 alleles as well as from mice lacking expression of caspase-8 and cells expressing FADD-DN were completely resistant to CD95-induced apoptosis in the presence of inhibitors of protein synthesis. Since apoptosis could be efficiently induced in murine T cells or two human tumor cell lines expressing one nonfunctional CD95 allele, caspase-8 can be activated in two ways, canonically, involving the classical formation of the DISC with wild-type CD95 and in a noncanonical fashion that does not require formation of the classical DISC and involves a form of caspase- 8 that is relatively insensitive to inhibition by zIETD-fmk and crmA while maintaining its sensitivity to zVADfmk.

In summary, our data suggest the following pathway in cells either expressing a mutated CD95 allele or Type I cells treated with S2/CHX: triggering of CD95 results in an inefficient recruitment of FADD and procaspase-8. Both FADD and procaspase- 8 are required since neither FADD-DN-expressing cells nor caspase-8-deficient cells can die through the novel pathway. Recruitment of enzymatically active procaspase- 8 to the activated receptor without conversion to active caspase- 8 subunits results in enough Bid cleavage to induce activation of mitochondria causing a delayed activation of caspase- 3 and apoptosis.

The dogma of the requirement of a functional DD for CD95 signaling was previously broken for a nonapoptotic pathway initiated by activation of MAP kinases. ${ }^{29}$ Our data demonstrate that in contrast to activation of MAP kinases by CD95, activation of caspase-8 through CD95 cannot occur without the expression of at least one allele of wild-type CD95. Our analysis allows us to predict that the CD95 apoptosis pathway can still be induced in many tumor cells in which the canonical DD-FADD-caspase-8 pathway fails to be activated either due to expression of mutated CD95, which usually only affects one CD95 allele, or in the case of Type I cells by stimulation with soluble CD95L. We determined in colony-forming assays that sCD95L alone did not negatively affect the ability of SKW6.4 cells to form colonies. It rather caused a slight increase in cloning efficiency of the cells consistent with CD95 having an activity to transmit positive signals into certain cells. ${ }^{30}$ However, SCD95L was found to be a potent inducer of apoptosis in Type I cells when protein synthesis was inhibited. That we did not observe a complete inhibition of colony formation was likely due to the limited preincubation period of the cells with $\mathrm{CHX}$. When we extended the time of preincubation to $16 \mathrm{~h}$, no colonies could be detected (data not shown). However, under these conditions $\mathrm{CHX}$ began to be toxic and any colonies formed were very small. Our study therefore suggests using specific inhibitors of NF- $\kappa B$ as a treatment which would then be constantly present likely increasing the toxicity of SCD95L. Our work could therefore have implications for tumor therapy involving CD95 apoptosisresistant cells.

\section{Materials and Methods}

\section{Cell lines}

The B lymphoblastoid cell line SKW6.4, the T cell lines H9, H9-3D8-FR, Hut78, FasEx08Del, Jurkat and CEM, and T-47D, NCl-H226, SF-295, ACHN, CAKI-1, UO-31 cells were cultured in RPMI 1640 supplemented with $10 \%$ FCS, $2 \mathrm{mM}$ glutamine, $100 \mathrm{U} / \mathrm{ml}$ penicillin and $100 \mu \mathrm{g} / \mathrm{ml}$ streptomycin and maintained in $5 \% \mathrm{CO}_{2}$ at $37^{\circ} \mathrm{C}$. MCF7-Fas-Bcl- $\mathrm{x}_{\mathrm{L}}$ were cultured in the same media supplemented with $200 \mu \mathrm{g} / \mathrm{ml} \mathrm{G418} \mathrm{(Cellgro,}$ Herndon, VA, USA) and $150 \mu \mathrm{g} / \mathrm{ml}$ Hygromycin B (Sigma). BJAB transfectants were maintained in RPMl 1640 supplemented with $10 \%$ FCS, $2 \mathrm{mM}$ glutamine, $100 \mathrm{U} / \mathrm{ml}$ penicillin, and $100 \mu \mathrm{g} / \mathrm{ml}$ streptomycin 
with $4 \mathrm{mg} / \mathrm{ml} \mathrm{G} 418$ and maintained in $5 \% \mathrm{CO}_{2}$ at $37^{\circ} \mathrm{C}$. SKW6 Bcl-2 cells were maintained in DMEM supplemented with $10 \%$ FCS, 2 mM glutamine, $100 \mathrm{U} / \mathrm{ml}$ penicillin and $100 \mu \mathrm{g} / \mathrm{ml}$ streptomycin with $1 \mathrm{mg} / \mathrm{ml} \mathrm{G} 418$ and $55 \mathrm{mM}$ tissue culture grade $\beta$-mercaptoethanol at $37^{\circ} \mathrm{C}$ in a $5 \% \mathrm{CO}_{2}$ atmosphere. The human embryonic kidney cell line 293T was cultured in DMEM supplemented with $10 \%$ FCS, $2 \mathrm{mM}$ glutamine, $100 \mathrm{U} / \mathrm{ml}$ penicillin and $100 \mu \mathrm{g} / \mathrm{ml}$ streptomycin at $37^{\circ} \mathrm{C}$ in a $5 \% \mathrm{CO}_{2}$ atmosphere. BJAB cells stably expressing either FADD-DN, crmA or an inactive crmA mutant were described before. ${ }^{21,31}$

\section{Antibodies, plasmids and reagents}

The mAb against FADD was purchased from Transduction Laboratories (Lexington, KY, USA). The rabbit polyclonal anti-CD95 (C20) and antiCD95L (C20) antibodies and the anti-Bid antibodies were purchased from Santa Cruz Biotechnologies (Santa Cruz, CA, USA). The anti-caspase-10 $\mathrm{mAb}$ (clone $4 \mathrm{C} 1$ ) was obtained from MBL International Corp. (Watertown, MA, USA). The anti-caspase-3, anti-caspase-6, anti-caspase-7 and anticaspase- 9 antibodies were obtained from Cell Signaling Technology (Beverly, MA, USA). The monoclonal anti-PARP antibody was purchased from BIOMOL (Plymouth Meeting, PA, USA). The C15 mAb recognizes the p18 subunit of caspase- $8 .{ }^{32}$ Anti-APO-1 is an agonistic monoclonal antibody $(\lg G 3, \kappa)$ recognizing an epitope on the extracellular portion of CD95. ${ }^{33}$ The neutralizing anti-CD95L antibody clone NOK-1, the mousespecific anti-CD3e (clone 2C11) and the agonistic hamster anti-mouse CD95 antibody Jo2 were purchased from BD Pharmingen (San Diego, CA, USA). The neutralizing anti-CD95 mAb ZB4 was from Upstate Biotechnology (Lake Placid, NY, USA). All other chemicals used were of analytical grade and purchased from Sigma, Molecular Probes (Eugene, OR, USA) or Calbiochem (San Diego, CA, USA). Plasmids to produce the recombinant soluble human CD95L, S1 and S2 and LzCD95L were described elsewhere. ${ }^{34,35}$ The following caspase inhibitors were from Calbiochem (San Diego, CA, USA): benzyloxycarbonyl(z)VDVADfluoromethylketone(fmk) (caspase-2), zDEVD-fmk (caspase-3/7), zVEIDfmk (caspase-6), zIETD-fmk (caspase-8), zLEHD-fmk (caspase-9). The oligocaspase inhibitor zVAD-fmk, the caspase-10 inhibitor ZAEVD-fmk, the calpain inhibitor ZLLY-fmk and the cathepsin $B$ and $K$ inhibitor zFA-fmk were from Enzyme Systems Products (Dublin, CA, USA). The general serine protease inhibitor 4-(2-aminoethyl)benzenesulfonyl fluoride (AEBSF) was from Sigma. Caffeic acid phenethyl ester (CAPE, Calbiochem), an inhibitor of NF- $\kappa$ B activation, ${ }^{7}$ was used at $2.5 \mu \mathrm{g} / \mathrm{ml}$. BAY 11-7082 was from Calbiochem and used at $10 \mu \mathrm{M}$ for $\mathrm{H} 9$ cells and at $5 \mu \mathrm{M}$ for SKW6.4 and BJAB cells. The rat IgG1 anti-mouse caspase-8 monoclonal antibody $1 \mathrm{G} 12^{36}$ was provided by $\operatorname{Dr} A$ Strasser.

\section{Colony-forming assay}

SKW6.4 cells $\left(10^{6}\right.$ in $\left.1 \mathrm{ml}\right)$ were incubated for $8 \mathrm{~h}$ with the indicated stimulus, $\mathrm{CHX}$ at $10 \mu \mathrm{g} / \mathrm{ml}$, S2 at $1 \mu \mathrm{g} / \mathrm{ml}$. Cells were then washed and plated in 96-well plates at 100 cells/well, 48 wells/condition. S2 was maintained in the culture for the duration of the assay. Colonies were scored 7 days after plating by light microscopy.

\section{DISC analysis and Western blotting}

The amount of DISC-associated components was determined as described previously. ${ }^{9}$ For detection of caspase and substrate cleavage in lysates following CD95L stimulation, cells were treated with $1 \mu \mathrm{g} / \mathrm{ml}$ of LzCD95L, $1 \mu \mathrm{g} / \mathrm{ml} \mathrm{S2}$ or $10 \mu \mathrm{g} / \mathrm{ml} \mathrm{CHX} \mathrm{(1} \mathrm{h} \mathrm{pretreatment)} \mathrm{plus} 1 \mu \mathrm{g} / \mathrm{ml} \mathrm{S} 2$ for various times. After stimulation, cells were lysed as above and $60 \mu \mathrm{g}$ of protein/lane was separated by SDS-PAGE and immunoblotted with the indicated antibodies.

\section{Generation of soluble CD95L}

To generate S1 and S2 ligands, 293T cells were transiently transfected using the calcium phosphate method. Briefly, $10^{6}$ cells were plated on $10 \mathrm{~cm}$ dishes and transfected with the viral caspase inhibitors crmA and p35 plus $10 \mu \mathrm{g}$ of the CD95L constructs: pEF-BOS-SIG-hFasL a.a. 103281 (S1) or pEF-BOS-hFasL a.a. 137-281 (S2). Cells were incubated for $72 \mathrm{~h}$ at $37^{\circ} \mathrm{C}$. Supernatants were harvested, centrifuged to remove cells and debris, and concentrated (10-fold) using centrifugal concentrators (10 kDa molecular weight cutoff). Concentrated supernatants were then filtered through $0.22 \mu \mathrm{m}$ filters. SCD95L in cell lysates and concentrated supernatant was characterized and quantified by Western blot using the anti-CD95L antibody clone C-20.

\section{Induction of apoptosis, cytotoxicity, cell morphology and caspase activity assays}

In total, $1.6 \times 10^{5}$ cells in $200 \mu$ l of medium were incubated in 96-well plates with different concentrations of anti-APO-1 or with the various forms of $\mathrm{CD} 95 \mathrm{~L}$ at $37^{\circ} \mathrm{C}$ for $16-22 \mathrm{~h}$. For cytotoxicity assays using adherent cells, $10^{5}$ cells were plated in $1 \mathrm{ml}$ of media in 12-well plates and allowed to adhere overnight. Cells were preincubated with caspase inhibitors for $45 \mathrm{~min}$ and stimulated as indicated. Detached and adherent cells were harvested $16 \mathrm{~h}$ after stimulation. Quantification of DNA fragmentation was carried out using the method of Nicoletti as previously described. ${ }^{3}$ Caspase- 3 and caspase- 8 activity in cell lysates was determined as previously described. ${ }^{37}$ Values of unstimulated cells were taken as background and subtracted from those obtained with stimulated cells.

\section{Flow cytometric analysis of mitochondrial membrane potential $\left(\Delta \Psi_{\mathrm{m}}\right)$}

To measure $\Delta \Psi_{\mathrm{m}}$, cells were stimulated with $1 \mu \mathrm{g} / \mathrm{ml} \mathrm{S2}$ or LzCD95L in the presence or absence of $10 \mu \mathrm{g} / \mathrm{ml}$ of $\mathrm{CHX}$ (1 h pretreatment) for the indicated times. Cells were harvested and incubated with $50 \mathrm{nM}$ MitoShift ${ }^{\mathrm{TM}}$ dye (Trevigen, Gaithersburg, MD, USA) for 30 min in darkness at room temperature. Cells were washed with PBS and analyzed immediately by flow cytometry. Values of unstimulated cells were taken as background and subtracted from those obtained with stimulated cells.

\section{Mouse strains, splenocyte isolation and stimulation}

$\mathrm{C} 3 \mathrm{H} \quad \mathrm{Ipr}^{\mathrm{cg}}$ mice $^{38}$ were bred with $\mathrm{C} 3 \mathrm{H}$ wild-type mice (Jackson Laboratories, Bar Harbor, ME, USA) to generate heterozygous mice. Tcell-specific caspase-8-deficient mice were described previously. ${ }^{18}$ Spleens were isolated and mechanically dissociated, followed by passage through $70 \mu \mathrm{m}$ nylon filters. Cells were incubated on plates that had been coated with $10 \mu \mathrm{g} / \mathrm{ml}$ anti-CD3 $\varepsilon$ antibody in PBS, by incubation in $50 \mathrm{U} / \mathrm{ml}$ IL-2 for 3 days. Cells were cultured in RPMI 1640 supplemented with $10 \%$ FCS, $2 \mathrm{mM}$ glutamine, $100 \mathrm{U} / \mathrm{ml}$ penicillin, $100 \mu \mathrm{g} / \mathrm{ml}$ streptomycin and $550 \mu \mathrm{M}$ tissue culture grade $\beta$-mercaptoethanol (Gibco, Grand Island, NY, USA) and maintained in $5 \% \mathrm{CO}_{2}$ at $37^{\circ} \mathrm{C}$. Viable, activated cells were isolated using Lymphocyte Separation Medium (BioWhittaker, Walkersville, MD, USA), washed, stimulated in 48-well plates $\left(0.4 \mathrm{ml}, 0.15 \times 10^{6}\right.$ cells) with indicated ligands or J02 at $10 \mu \mathrm{g} / \mathrm{ml}$ with $10 \mathrm{ng} / \mathrm{ml}$ protein $A$ 
(Sigma) for $18 \mathrm{~h}$ with or without $0.1 \mu \mathrm{g} / \mathrm{ml} \mathrm{CHX}$ as indicated and subjected to DNA fragmentation analysis as described above. Western blot analysis was performed on cells stimulated as indicated $(1 \mu \mathrm{g} / \mathrm{ml}$ CD95L, $0.1 \mu \mathrm{g} / \mathrm{ml}$ $\mathrm{CHX}, 4 \mathrm{~h}$ preincubation) as described above using $20 \mu \mathrm{g}$ of lysate.

\section{Biotin-zVAD labeling of active caspases}

In all, $5 \times 10^{7}$ SKW6. 4 cells were preincubated for $1 \mathrm{~h}$ with $10 \mathrm{mg} / \mathrm{ml} \mathrm{CHX}$ followed by stimulation with either LzCD95L or S2 for the indicated time at $2 \times 10^{6}$ cells $/ \mathrm{ml}$. Cells were then concentrated into $1 \mathrm{ml}$ and biotin-zVAD (MP Biochemicals) was added to $100 \mu \mathrm{M}$ for $1 \mathrm{~h}$ at $37^{\circ} \mathrm{C}$. Cells were then lysed with $1 \mathrm{ml}$ lysis buffer as above. Lysates were cleared by centrifugation and streptavidin-agarose beads added and rocked at $4{ }^{\circ} \mathrm{C}$ for $2 \mathrm{~h}$. Beads were extensively washed in lysis buffer and subjected to Western blot analysis for caspase-8 and caspase- 3 .

\section{Acknowledgements}

We thank Drs $\mathrm{P}$ Krammer and $\mathrm{H}$ Walczak for providing us with anti-APO-1 and LzCD95L, respectively. We are grateful for Drs R DeMaria, A Payne and $V$ Dixit for the Hut78 and $\mathrm{H} 9$ mutant cells and the crmA-expressing BJAB cells, respectively. The expression construct for human soluble CD95L was kindly provided by Dr S Nagata and the anti-mouse caspase-8 antibody by $\mathrm{Dr} A$ Strasser. This work was funded by the NIH Grant GM61712. A A-S was supported by the Cancer Biology Training Program 5T32CA09594 and BC. Barnhart by the DOD Breast Cancer Research Program DAMD17-03-1-0200.

\section{References}

1. Peter ME and Krammer PH (2003) The CD95(APO-1/Fas) DISC and beyond. Cell Death Differ. 10: 26-35

2. Barnhart BC, Alappat EC and Peter ME (2003) The CD95 type I/type II model. Semin. Immunol. 15: 185-193

3. Algeciras-Schimnich A, Pietras EM, Barnhart BC, Legembre P, Vijayan S, Holbeck SL and Peter ME (2003) Two CD95 tumor classes with different sensitivities to antitumor drugs. Proc. Natl. Acad. Sci. USA 100: 11445-11450

4. Muschen M, Rajewsky K, Kronke M and Kuppers R (2002) The origin of CD95gene mutations in B-cell lymphoma. Trends Immunol. 23: 75-80

5. Kischkel FC, Hellbardt S, Behrmann I, Germer M, Pawlita M, Krammer PH and Peter ME (1995) Cytotoxicity-dependent APO-1 (Fas/CD95)-associated proteins form a death-inducing signaling complex (DISC) with the receptor. EMBO J. 14: $5579-5588$

6. Siegel RM, Frederiksen JK, Zacharias DA, Chan FK, Johnson M, Lynch D, Tsien RY and Lenardo MJ (2000) Fas preassociation required for apoptosis signaling and dominant inhibition by pathogenic mutations. Science 288 : 2354-2357

7. Natarajan K, Singh S, Burke Jr TR, Grunberger D and Aggarwal BB (1996) Caffeic acid phenethyl ester is a potent and specific inhibitor of activation of nuclear transcription factor NF-kappa B. Proc. Natl. Acad. Sci. USA 93: 9090-9095

8. Mori N, Yamada Y, Ikeda S, Yamasaki Y, Tsukasaki K, Tanaka Y, Tomonaga M, Yamamoto N and Fujii M (2002) Bay 11-7082 inhibits transcription factor NF-kappaB and induces apoptosis of HTLV-I-infected T-cell lines and primary adult T-cell leukemia cells. Blood 100: 1828-1834

9. Scaffidi C, Fulda S, Srinivasan A, Friesen C, Li F, Tomaselli KJ, Debatin KM, Krammer PH and Peter ME (1998) Two CD95 (APO-1/Fas) signaling pathways. EMBO J. 17: 1675-1687

10. Liu N, Raja SM, Zazzeroni F, Metkar SS, Shah R, Zhang M, Wang Y, Bromme D, Russin WA, Lee JC, Peter ME, Froelich CJ, Franzoso G and AshtonRickardt PG (2003) NF-kappaB protects from the lysosomal pathway of cell death. EMBO J. 22: 5313-5322
11. Lu T, Xu Y, Mericle MT and Mellgren RL (2002) Participation of the conventional calpains in apoptosis. Biochim. Biophys. Acta 1590: $16-26$

12. Thorburn J, Bender LM, Morgan MJ and Thorburn A (2003) Caspase- and serine protease-dependent apoptosis by the death domain of FADD in normal epithelial cells. Mol. Biol. Cell 14: 67-77

13. Muschen M, Warskulat $U$ and Beckmann MW (2000) Defining CD95 as a tumor suppressor gene. J. Mol. Med. 78: 312-325

14. Barnhart BC, Legembre P, Pietras EM, Bubici C, Franzoso G and Peter ME (2004) CD95 ligand induces motility and invasiveness of apoptosis resistant tumor cells. EMBO J. 23: 3175-3185

15. Delehanty LL, Payne JA, Farrow SN, Brown R and Champion BR (1997) Apoptosis in a Fas-resistant, T-cell receptor-sensitive human leukaemic T-cell clone. Immunology 90: 383-387

16. Cascino I, Papoff G, De Maria R, Testi R and Ruberti G (1996) Fas/Apo-1 (CD95) receptor lacking the intracytoplasmic signaling domain protects tumor cells from Fas-mediated apoptosis. J. Immunol. 156: 13-17

17. Matsuzawa A, Shimizu M, Takeda $Y$, Nagase $H$, Sayama $K$ and Kimura $M$ (2002) Significant role of Fas ligand-binding but defective Fas receptor (CD95) in lymph node hyperplasia composed of abnormal double-negative $\mathrm{T}$ cells. Immunology 106: 470-475

18. Salmena L, Lemmers B, Hakem A, Matysiak-Zablocki E, Murakami K, Au PY, Berry DM, Tamblyn L, Shehabeldin A, Migon E, Wakeham A, Bouchard D, Yeh WC, McGlade JC, Ohashi PS and Hakem R (2003) Essential role for caspase 8 in T-cell homeostasis and T-cell-mediated immunity. Genes Dev. 17: 883-895

19. Chang DW, Xing Z, Capacio VL, Peter ME and Yang X (2003) Interdimer processing mechanism of procaspase-8 activation. EMBO J. 22 $4132-4142$

20. Stegh AH, Barnhart BC, Volkland J, Algeciras-Schimnich A, Ke N, Reed JC and Peter ME (2002) Inactivation of caspase-8 on mitochondria of Bcl-xLexpressing MCF7-Fas cells: role for the bifunctional apoptosis regulator protein. J. Biol. Chem. 277: 4351-4360

21. Medema JP, Scaffidi C, Kischkel FC, Shevchenko A, Mann M, Krammer PH and Peter ME (1997) FLICE is activated by association with the CD95 deathinducing signaling complex (DISC). EMBO J. 16: 2794-2804

22. Zhou Q, Snipas S, Orth K, Muzio M, Dixit VM and Salvesen GS (1997) Target protease specificity of the viral serpin CrmA. Analysis of five caspases. J. Biol. Chem. 272: 7797-7800

23. Schneider P, Holler N, Bodmer JL, Hahne M, Frei K, Fontana A and Tschopp J (1998) Conversion of membrane-bound Fas(CD95) ligand to its soluble form is associated with downregulation of its proapoptotic activity and loss of liver toxicity. J. Exp. Med. 187: 1205-1213

24. Tanaka M, Itai T, Adachi M and Nagata S (1998) Downregulation of Fas ligand by shedding. Nat. Med. 4: 31-36

25. Leist M, Gantner F, Bohlinger I, Germann PG, Tiegs G and Wendel A (1994) Murine hepatocyte apoptosis induced in vitro and in vivo by TNF-alpha requires transcriptional arrest. J. Immunol. 153: 1778-1788

26. Fulda S, Meyer E and Debatin KM (2000) Metabolic inhibitors sensitize for CD95 (APO-1/Fas)-induced apoptosis by down-regulating Fas-associated death domain-like interleukin 1-converting enzyme inhibitory protein expression. Cancer Res. 60: 3947-3956

27. Holler N, Zaru R, Micheau O, Thome M, Attinger A, Valitutti S, Bodmer JL, Schneider P, Seed B and Tschopp J (2000) Fas triggers an alternative, caspase-8-independent cell death pathway using the kinase RIP as effector molecule. Nat. Immunol. 1: 489-495

28. Vercammen D, Brouckaert G, Denecker G, Van de Craen M, Declercq W, Fiers W and Vandenabeele P (1998) Dual signaling of the Fas receptor: initiation of both apoptotic and necrotic cell death pathways. J. Exp. Med. 188: 919-930

29. Desbarats J, Birge RB, Mimouni-Rongy M, Weinstein DE, Palerme JS and Newell MK (2003) Fas engagement induces neurite growth through ERK activation and p35 upregulation. Nat. Cell Biol. 5: 118-125

30. Alderson MR, Armitage RJ, Maraskovsky E, Tough TW, Roux E, Schooley K, Ramsdell F and Lynch DH (1993) Fas transduces activation signals in normal human T lymphocytes. J. Exp. Med. 178: 2231-2235

31. Scaffidi C, Volkland J, Blomberg I, Hoffmann I, Krammer $\mathrm{PH}$ and Peter ME (2000) Phosphorylation of FADD/MORT1 at serine 194 and 
association with a 70-kDa cell cycle-regulated protein kinase. J. Immunol. 164: 1236-1242

32. Scaffidi C, Medema JP, Krammer PH and Peter ME (1997) FLICE is predominantly expressed as two functionally active isoforms, caspase-8/a and caspase-8/b. J. Biol. Chem. 272: 26953-26958

33. Trauth BC, Klas C, Peters AM, Matzku S, Moller P, Falk W, Debatin KM and Krammer PH (1989) Monoclonal antibody-mediated tumor regression by induction of apoptosis. Science 245: 301-305

34. Tanaka M, Suda T, Takahashi T and Nagata S (1995) Expression of the functional soluble form of human fas ligand in activated lymphocytes. EMBO J. 14: $1129-1135$

35. Walczak H, Degli-Esposti MA, Johnson RS, Smolak PJ, Waugh JY, Boiani N Timour MS, Gerhart MJ, Schooley KA, Smith CA, Goodwin RG and Rauch CT
(1997) TRAIL-R2: a novel apoptosis-mediating receptor for TRAIL. EMBO J. 16: $5386-5397$

36. O'Reilly LA, Divisekera U, Newton K, Scalzo K, Kataoka T, Puthalakath H, Ito $M$, Huang DC and Strasser A (2004) Modifications and intracellular trafficking of FADD/MORT1 and caspase-8 after stimulation of T lymphocytes. Cell Death Differ. 11: 724-736

37. Algeciras-Schimnich A and Peter ME (2003) Actin dependent CD95 internalization is specific for Type I cells. FEBS Lett. 546: 185-188

38. Yasuda T, Zhang Y, Nagase H, Kaneko T, Sayama K, Hashimoto H and Matsuzawa $\mathrm{A}$ (2000) Immunological characterization of $\mathrm{C} 3 \mathrm{H}$ mice congenic for Fas(lprcg), C3h/HeJ-Fas(lprcg)/Fas(lprcg). Lab. Anim. 34: 46-55

39. Peter ME, Legembre $P$ and Barnhart BC. CD95 (APO-1/Fas), a tumor suppressor turned tumor promotor? 